\title{
Evaluation of Antimalarial Activity of the Leaf Latex and TLC Isolates from Aloe megalacantha Baker in Plasmodium berghei Infected Mice
}

\author{
Gebretsadkan Hintsa $(\mathbb{D}$, Gereziher Geremedhin Sibhat, and Aman Karim \\ Department of Pharmacognosy, School of Pharmacy, College of Health Sciences, Mekelle University, P.O. Box 1871, Mekelle, Ethiopia
}

Correspondence should be addressed to Gebretsadkan Hintsa; gebretsadkan.hintsa@mu.edu.et

Received 17 October 2018; Accepted 19 March 2019; Published 14 April 2019

Academic Editor: Ian Cock

Copyright (C) 2019 Gebretsadkan Hintsa et al. This is an open access article distributed under the Creative Commons Attribution License, which permits unrestricted use, distribution, and reproduction in any medium, provided the original work is properly cited.

\begin{abstract}
Malaria is a devastating parasitic disease which caused around 216 million cases and 445,000 deaths worldwide in 2016. This might be attributed to a wide spread of drug resistant parasites. The plant Aloe megalacantha is indigenous to Ethiopia where the sap of the leaves is traditionally used for the treatment of malaria. This study was aimed at evaluating the antimalarial effect of leaf latex and isolates obtained from Aloe megalacantha against chloroquine sensitive Plasmodium berghei ANKA strain in Swiss albino mice. Peters' 4-day suppressive test method was used to test the antimalarial activity of both leaves latex and isolates. Three isolates were obtained using thin layer chromatography and were coded as $\mathrm{AM}_{1}, \mathrm{AM}_{2}$, and $\mathrm{AM}_{3}$ in ascending order of their retention factor. After treatment of Plasmodium berghei infected mice with leaf latex of Aloe megalacantha for four days at 100, 200, and 400 mg/kg, it shows $30.3 \%, 43.4 \%$, and $56.4 \%$ suppression of the parasite growth, respectively. $32.3 \%, 51.3 \%$, and $67.4 \%$ chemosuppression after treatment with $\mathrm{AM}_{1}, 39.8 \%, 50.6 \%$, and $64.2 \%$ chemosuppression after treatment with $\mathrm{AM}_{2}$, and $52.6 \%, 69.4 \%$, and $79.6 \%$ chemosuppression after treatment with $\mathrm{AM}_{3}$ were observed at doses of 100,200 , and $400 \mathrm{mg} / \mathrm{kg} /$ day, respectively. The observed parasite suppression of leaves latex and isolates was statistically significant $(\mathrm{P}<0.05)$ as compared to negative control. Moreover, both the leaves latex and isolates were also observed to prevent Plasmodium berghei induced body weight loss and hypothermia and increased the survival time of Plasmodium berghei infected mice as compared to the negative control. Hence, the present study supports the traditional claim of the plant for the treatment of malaria.
\end{abstract}

\section{Background}

Malaria is the most devastating infectious disease caused by the protozoan parasites belonging to the genus Plasmodium. There are five parasite species that cause malaria in humans, namely, Plasmodium falciparum, Plasmodium vivax, Plasmodium malariae, Plasmodium ovale, and Plasmodium knowlesi, with $P$. falciparum causing the most severe form of malaria and hence higher mortality rates [1]. Despite the progress in reducing malaria cases and deaths, beyond half of the total population are still at risk of infection with malaria. Malaria has been reported to cause 216 million cases and 445,000 deaths globally in 2016. From these, approximately $90 \%$ of the cases and $91 \%$ of the deaths were in the African region. It has reported that about $70 \%$ of the deaths were in children less than 5 years of age [2]. In addition to the suffering of individuals due to malaria, it weakens the economy of developing countries and it is the leading causes of outpatient visits and hospital admission because of different reasons such as limited number of antimalarial drugs, rapid emergence of drug resistant strains of parasite, and emergence of new Plasmodium species, particularly $P$. knowlesi [3]. These problems encouraged the urgent need to develop new affordable and safe antimalarials with novel modes of action. One approach to this is searching novel antimalarial drugs from traditionally acclaimed medicinal plants $[4,5]$.

Nearly $80 \%$ of population of the world still rely heavily on traditional healers and need medicinal plants for treatment of various kinds of ailments. Traditional medicines are often more available, affordable, and sometimes are perceived as more effective than modern drugs [6,7]. Medicinal plants 
most frequently used in Ethiopia and neighboring countries as traditional medicine for the treatment of malaria include Acalypha fruticosa, Azadirachta indica, Dendrosicyos socotrana [6], Ajuga integrifolia, Melia azedarach, Peponium vogelii, Premna schimperi, Clerodendrum myricoides, Croton macrostachyus, Fagaropsis angolensis [8], Dodonaea angustifolia, Aloe debrana [9], Aloe species, Azadirachta indica, Tamarindus indica $[8,10,11]$, Gardenia ternifolia, Indigofera spicata [12], and Combretum molle [13].

Aloes especially $A$. vera have a very long history of medicinal, cosmetic, and cultural uses. There are about 600 different Aloe species recognized so far; most of them are native to South Africa, the Arabian Peninsula, Madagascar, and other islands of the western Indian Ocean [14]. Ethiopia has 46 species of Aloe, of these Aloe megalacantha is indigenous to Ethiopia and rarely found in Northern Somalia $[15,16]$.

The leaf latex of Aloe species is used particularly for the treatment of malaria, bacterial infections, fungal infections, parasitic diseases, gastrointestinal disorders, and inflammations $[14,17]$. In Northern and Eastern Ethiopia, people use leaf latex of $A$. megalacantha Baker as a folklore medicine for the treatment of different illnesses including malaria, wound, constipation, abdominal pain, impotence, urine retention, snake bite, and amoebiasis [7, 18-20]. However, the traditional use of $A$. megalacantha for malaria treatment is not yet scientifically validated.

Previous in vivo and in vitro studies have shown Aloe species possessing strong antimalarial activity. In vitro antiplasmodial activity of leaf extracts and isolated compounds obtained from $A$. vera has been tested using chloroquine sensitive $P$. falciparum and reported showing a dosedependent chemosuppresive effect [21]. Similar studies to assess antimalarial activity using 4-day suppressive test method in P. berghei infected mice model of other Aloe species have also been conducted which include studies on methanolic leaf extract of A. debrana [9] and leaf latex and isolated compounds of A. percrassa [22], A. citrana [23], and A. pulcherrima [24].

Leaf latex of A. megalacantha has shown a significant wound healing activity in both excision and incision model. It has also possessed good anti-inflammatory effect in carrageenan induced paw edema model [25]. Ethyl acetate root extract and isolated natural products of $A$. megalacantha have been evaluated for their cytotoxic activities against a human cervix carcinoma cell line KB-3-1 with cryptophycin$52\left(\mathrm{IC}_{50}=1.3 \times 10^{-5} \mu \mathrm{M}\right)$ and griseofulvin $\left(\mathrm{IC}_{50}=19.0 \mu \mathrm{M}\right)$ as a standard drugs. The study has been conducted on the basis of its traditional use for wound treatment. The isolates have exhibited good cytotoxic activity with aloesaponarin II $\left(\mathrm{IC}_{50}=0.98 \mu \mathrm{M}\right)$ possessing the highest activity as compared to the other isolates and the standard drug griseofulvin [26].

Hence, the present study was conducted to evaluate the antimalarial activity of leaves latex and thin layer chromatography (TLC) isolates from A. megalacantha using 4day suppressive test method in an experimental animal model. The present study was also done to justify the traditional use of this plant product. This study may provide baseline information for the scientific community about the chemosuppressive effect of the specific traditional medicine.

\section{Materials and Methods}

2.1. Plant Material. The leaves latex of Aloe megalacantha was collected from Kilte Awulaelo district locality called Genfel which is located at $47.7 \mathrm{~km}$ north of the regional city, Mekelle, Northern Ethiopia. The plant material was authenticated by Professor Sebsebe Demissew, Department of Biology, Addis Ababa University, and a voucher number GH001 of the specimen was deposited in National herbarium, Department of Biology, Addis Ababa University.

2.2. Instruments, Chemicals, Reagents, and Drugs. The chemicals, reagents, and drugs listed below were used to perform the experiments: chloroform with batch number V3M521074A (CALRO EBRA reagents, France;), methanol with batch number V4H4376174I (CALRO EBRA reagents, France), silica gel type $G$ with batch number 126K0028 (Sigma-Aldrich, USA), Giemsa stain, immersion oil, tween 80, chloroquine phosphate (Addis Pharmaceutical Factory PLC, Adigrat, Ethiopia), sodium citrate, distilled water, and normal saline $(0.9 \%)$. All the chemicals and reagents used were analytical grade and purchased from market.

Drying oven (GENLAB WIDNES, England), TLC glass plate, TLC jar (CAMAG, Germany), Automatic TLC coater (CAMAG, Germany), UV cabinet (CAMAG, Germany), Compound Microscope (Olympus, Germany), oral gavages, stop watch, electronic weighing balance (Adventurer OHAUS, China), and digital thermometer were also used to conduct the study.

\subsection{Experimental Animals and Plasmodium berghei. Swiss} albino mice of male sex, weighing $20-25 \mathrm{~g}$ and aged of 68 weeks, were used to study the antimalarial activity and female Swiss albino mice weighing 25-30g with 8-12 weeks of age were used to conduct acute oral toxicity test. The experimental mice were obtained from the animal house of School of Pharmacy, Mekelle University, Ethiopia. They were fed with pellet and water ad libitum. The mice were used as per the international guideline for care and use of the experimental animals. These mice were housed in a standardized room which has an artificial lighting $12 \mathrm{hr}$ per day to acclimatize them to the laboratory environment [27]. The mice used on the study were euthanized at the end of follow-up period using a chemical method (Halothane in a desiccator). Chloroquine sensitive Plasmodium berghei ANKA strain was brought from Ethiopian Public Health Institute (EPHI) and maintained by serial passage of blood from infected mice (donor mice) to the noninfected ones on weekly basis.

2.4. Extract Preparation. The leaf latex was extracted and prepared as per the procedure described by Geremedhin et $a l$. The leaves of $A$. megalacantha were cut transversally near the base and then inclined in a plastic material to collect the yellow sap from inside of the leaf. Finally, the collected sap was left in shaded open air for two to three days by flooding 
in wide spaced plastic material to make a thin film by which suiting the evaporation of water content of the sap which then resulted in golden latex [22].

\subsection{Isolation of Compounds}

2.5.1. Preparative Thin Layer Chromatography (PTLC). Isolation commenced after antimalarial activity of the leaf latex of A. megalacantha was established. Isolates were obtained from leaves latex using preparative thin layer chromatography (TLC) prepared by coating the glass plate with silica gel type G (Size: 10-40 $\mu$, Sigma-Aldrich, USA) at $0.5 \mathrm{~mm}$ thickness in the laboratory of Pharmacognosy department with the automatic TLC coater (CAMAG, Germany). The dried leaves latex was dissolved in methanol and applied directly as a band to the coated preparative TLC $(20 \mathrm{~cm} \times 20 \mathrm{~cm})$ over one side of the plate. Chloroform and methanol mixture (4:1) were used as a solvent system to develop the chromatogram $[22,24,28]$. The isolates were checked for their purity using silica gel over TLC plate ( $0.25 \mathrm{~mm}$ thickness).

2.5.2. Visualization. The chromatographic zones were visualized first in daylight and then by using ultraviolet light of wave length 254 and $366 \mathrm{~nm}$ in UV lamp. After visualization the chromatographic zones were coded based on ascending order of retention factor $\left(\mathrm{R}_{f}\right)$ values. Then, each band was carefully scrapped off separately from the plate and dissolved in methanol and chloroform (1:1), filtered, and concentrated.

2.6. Acute Oral Toxicity Test. Nulliparous and nonpregnant female Swiss albino mice were used for acute oral toxicity study. The study was conducted as per the internationally accepted protocol drawn under Organization for Economic Cooperation and Development (OECD) guidelines 425 [29]. Limit test protocol of the OECD guideline was followed for this experiment as similar Aloe species have been reported till the dose of $2000 \mathrm{mg} / \mathrm{kg}$ [22-25]. A total of five mice were used for the leaf latex of $A$. megalacantha and deprived from food for $3 \mathrm{hrs}$ before administration and $1 \mathrm{hr}$ after administration of the test sample. One mouse was administered leaf latex orally at a dose of $2000 \mathrm{mg} / \mathrm{kg}$ by using oral gavage and observed for $48 \mathrm{hrs}$ for any toxicity signs. After $48 \mathrm{hrs}$, four additional mice were administered with the leaf latex at a dose of $2000 \mathrm{mg} / \mathrm{kg}$. After the administration of the leaf latex, every mouse was observed continuously for the first $30 \mathrm{~min}$; intermittently over a period of $24 \mathrm{hrs}$; and daily for 14 days for the presence of changes in skin and fur, eye and mucous membrane secretions, tremors, convulsions, diarrhea, lethargy, sleep, and coma. Body weight of each mouse was recorded on the first day, seventh day, and fourteenth day [29].
The acute oral toxicity studies of the TLC isolates were conducted using the above protocol used for leaf latex. All test samples were dissolved in distilled water except the third isolate $\left(\mathrm{AM}_{3}\right)$ which was dissolved in 3\% tween 80 .

\subsection{In Vivo Antimalarial Activity Test}

2.7.1. Preparation of the Inoculums. The parasites were maintained by serial passage of blood from infected mice (donor mice) to the noninfected ones on weekly basis. Blood sample, which was taken from donor mouse with the growing parasitaemia of $20-30 \%$, was diluted using normal saline $(0.9$ $\%)$ to prepare an approximate of $5 \times 10^{7}$ infected erythrocytes per milliliter of blood suspension. So, each $0.2 \mathrm{ml}$ of blood suspension contains approximately $10^{7}$ infected erythrocytes, which were the standard inoculums used to infect each experimental animals intraperitoneally (ip).

2.7.2. Antimalarial Activity Test. The in vivo antimalarial activity of the leaves latex and isolates was evaluated by the method of Peter's 4-day suppressive test on Plasmodium berghei infected Swiss albino mice [30]. The mice were housed in standard transparent cages and maintained on pellet and water ad libitum for 7 days to acclimatize the laboratory environment. 25 male mice of 6-8-week age and weighing 20 $25 \mathrm{~g}$ were infected with $0.2 \mathrm{ml}$ blood suspension (about $1 \times 10^{7}$ parasitized RBC) intraperitoneally and randomly divided into five groups of five mice per group with three experimental groups and two control groups (one for chloroquine as a positive control and the other distilled water or vehicle as a negative control) for each test sample.

The leaf latex was prepared at three different doses of 100 , 200 , and $400 \mathrm{mg} / \mathrm{kg}$ of body weight of mice and chloroquine at $25 \mathrm{mg} / \mathrm{kg}$ in a volume of $1 \mathrm{ml} / 100 \mathrm{~g}$ body weight of the mice. The leaf latex or the standard was administered as a single dose per day and given through oral route using standard oral gavage. Treatment was started $3 \mathrm{~h}$ after infection on day 0 and was then continued daily for four days (i.e., from day 0 to day 3$)$ in order of their infection time. On the fifth day $\left(D_{4}\right)$, thin smears of blood films were obtained from the tail of each mouse and smeared on microscope from the first infected mice first and then in order of their infection time. Then, the smears were fixed with absolute methanol and stained with $10 \%$ Giemsa solution for $15 \mathrm{~min}$. The chemosuppression effect of each TLC isolates was tested using the above-mentioned method i.e., 4-day suppressive test method which was applied to test the antimalarial activity of leaf latex. Parasitemia level was determined by counting the number of parasitized erythrocytes out of three random fields of the microscope from each slide. Average percent parasitemia and suppression were calculated using the following formula [22].

$$
\begin{aligned}
& \% \text { Parasitemia }=\frac{\text { Number of parasitized } \mathrm{RBC}}{\text { Total number of RBC count }} \times 100 \\
& \% \text { Suppression }=\frac{\text { Mean parasitemia of negative control }- \text { Mean parasitemia of treatment }}{\text { Mean parasitemia of negative control }} \times 100
\end{aligned}
$$


TABLE 1: Percentage suppression and mean survival time of Plasmodium berghei infected mice after treatment with leaf latex and TLC isolates obtained from A. megalacantha.

\begin{tabular}{|c|c|c|c|c|}
\hline Test substance & Dose (mg/kg/day) & $\%$ Parasitemia \pm SEM & \%Suppression & MST (days) \\
\hline $\mathrm{NC}$ & $10 \mathrm{ml} / \mathrm{kg}$ & $47.0 \pm 3.49$ & 0.00 & $6.4 \pm 0.25$ \\
\hline \multirow[t]{3}{*}{ Latex } & 100 & $32.7 \pm 1.21 * *$ & 30.4 & $7.2 \pm 0.37$ \\
\hline & 200 & $26.6 \pm 2.99 * *$ & 43.4 & $9.0 \pm 0.51 *$ \\
\hline & 400 & $20.5 \pm 1.22 * *$ & 56.4 & $10.1 \pm 0.51 * *$ \\
\hline \multirow[t]{3}{*}{$\mathrm{AM}_{1}$} & 100 & $31.8 \pm 5.05 * *$ & 32.3 & $7.6 \pm 0.6$ \\
\hline & 200 & $22.9 \pm 3.73 * *$ & 51.3 & $8.8 \pm 0.58 *$ \\
\hline & 400 & $15.3 \pm 3.78 * *$ & 67.4 & $10.0 \pm 0.84 * *$ \\
\hline \multirow[t]{3}{*}{$\mathrm{AM}_{2}$} & 100 & $28.3 \pm 5.90 * *$ & 39.8 & $7.8 \pm 0.49$ \\
\hline & 200 & $23.2 \pm 3.90 * *$ & 50.6 & $8.8 \pm 0.37 *$ \\
\hline & 400 & $16.8 \pm 4.19 * *$ & 64.2 & $9.6 \pm 0.68 * *$ \\
\hline \multirow[t]{3}{*}{$\mathrm{AM}_{3}$} & 100 & $22.3 \pm 4.77 * *$ & 52.6 & $8.2 \pm 0.58 *$ \\
\hline & 200 & $14.4 \pm 2.38 * *$ & 69.4 & $9.6 \pm 0.55 * *$ \\
\hline & 400 & $9.6 \pm 1.75 * *$ & 79.6 & $10.4 \pm 0.51 * *$ \\
\hline CQ & 25 & $0.00 * *$ & 100 & ND \\
\hline
\end{tabular}

Values are presented $\mathrm{M} \pm \mathrm{SEM} ; \mathrm{n}=5 ; *$ mean value is significant $(P<0.05)$ and $* *$ mean value highly significant $(\mathrm{P}<0.001)$ when compared with negative control (NC) group; $\mathrm{ND}=$ no death within the follow-up period; $\mathrm{MST}=$ mean survival time in days.

2.7.3. Determination of Body Weight and Temperature. Body weight $[22,24]$ and rectal temperature [31] of each mouse in all groups were measured before infection (day 0 ) and on day 4 using electronic balance and digital thermometer, respectively, to observe the effect of the test sample in body weight and temperature of each mouse in all groups.

2.7.4. Determination of Mean Survival Time. Mortality was monitored daily and the number of days from the time of inoculation of the parasite up to death was recorded for each mouse in the treatment and control groups throughout the follow-up period of 28 days $\left(\mathrm{D}_{0}-\mathrm{D}_{27}\right)$ for all test samples $[22,27]$. The mean survival time (MST) for each group was then calculated using the following formula:

$$
\begin{aligned}
& \text { MST } \\
& =\frac{\text { Sum of the survival time of mice in a group (days) }}{\text { The total number of mice in that group }}
\end{aligned}
$$

2.8. Data Analysis. Results were analyzed by using software SPSS version 21 and reported as a mean \pm standard error of mean $(M \pm S E M)$. The one-way analysis of variance (ANOVA) followed by Tukey HSD post hoc test was used to compare results among and within groups. The results were considered significant when $\mathrm{P}<0.05$.

\section{Results}

3.1. Isolation of Compounds from Leaf Latex of Aloe megalacantha. Three yellow amorphous solid isolates were isolated from leaves latex of Aloe megalacantha with $R_{f}$ values of 0.33 , 0.49 , and 0.62 using repeated preparative TLC coated with silica gel in chloroform/methanol (4:1) solvent system. The isolates were coded as $\mathrm{AM}_{1}, \mathrm{AM}_{2}$, and $\mathrm{AM}_{3}$ in ascending order of their $R_{f}$ values. The isolates appeared as bright yellow when viewed under day light, seen as dark spot under UV light of $254 \mathrm{~nm}$ and striking yellow under UV light of 366 $\mathrm{nm}$.

3.2. Oral Acute Toxicity Test. The oral acute toxicity study showed that neither mortality nor signs and symptoms of toxicity were caused during the follow-up period after oral administration of the leaves latex or TLC isolates obtained from A. megalacantha at a dose of $2000 \mathrm{mg} / \mathrm{kg}$. It was also shown that there was no significant weight change after the administration of each test sample.

3.3. In Vivo Antimalarial Activity. Chemosuppression effect against $P$. berghei in mice was observed after testing the leaves latex and then after TLC isolates $\left(\mathrm{AM}_{1}, \mathrm{AM}_{2}\right.$, and $\left.\mathrm{AM}_{3}\right)$ obtained from leaves latex of A. megalacantha using Peter's 4-day suppressive test method. Among the tested samples, as shown in Table 1, the highest inhibition of parasitemia growth was recorded after administration of $\mathrm{AM}_{3}$ at a dose of $400 \mathrm{mg} / \mathrm{kg}$ body weight of mice. The result also showed that all the tested samples have dose-dependent antiplasmodial activity; i.e., enhanced suppression of parasitemia growth was observed with increasing the dose of the latex or either of the isolates. Thus, after the administration of the leaves latex, $\mathrm{AM}_{1}, \mathrm{AM}_{2}$, and $\mathrm{AM}_{3}$ for 4 days at doses of $400 \mathrm{mg} / \mathrm{kg} / \mathrm{day}$, they caused $56.4 \%, 67.4 \%, 64.2 \%$, and $79.6 \%$ suppression of parasite growth, respectively, with the corresponding vehicle treated mice which got $47.0 \pm 3.49 \%$ percentage parasitemia. The parasite growth inhibitions observed after treatment with latex, $\mathrm{AM}_{1}, \mathrm{AM}_{2}$, or $\mathrm{AM}_{3}$ at three different doses were statistically significant $(\mathrm{P}<0.001)$ when compared to the vehicle treated group (negative control). Chloroquine was observed to absolve the $P$. berghei infected mice from the parasite on the fifth day of the infection time which was significant $(\mathrm{P}<0.001)$ when compared to the negative control 
TAble 2: Body weight of Plasmodium berghei infected mice after administration of the leaf latex and TLC isolates of Aloe megalacantha.

\begin{tabular}{lcccc}
\hline Test substance & Dose $(\mathrm{mg} / \mathrm{kg} /$ day $)$ & $\mathrm{Wt} \mathrm{D}_{0}(\mathrm{~g})$ & $\mathrm{Wt} \mathrm{D}_{4}(\mathrm{~g})$ & Mean difference \\
\hline $\mathrm{NC}$ & $10 \mathrm{ml} / \mathrm{kg}$ & $21.9 \pm 0.63$ & $20.9 \pm 0.64$ & $-1.0(4.6)$ \\
Latex & 100 & $23.2 \pm 0.48$ & $23.1 \pm 0.44$ & $-0.1(0.4)$ \\
& 200 & $21.4 \pm 1.22$ & $21.7 \pm 1.01$ & $0.3(1.4)$ \\
& 400 & $20.1 \pm 0.23$ & $21.2 \pm 0.59$ & $1.1(5.5)$ \\
$\mathrm{AM}_{1}$ & 100 & $20.6 \pm 0.38$ & $20.8 \pm 0.42$ & $0.2(1.0)$ \\
& 200 & $20.7 \pm 0.38$ & $21.6 \pm 0.32$ & $0.9(4.4)$ \\
$\mathrm{AM}_{2}$ & 400 & $21.1 \pm 0.35$ & $22.4 \pm 0.56$ & $1.3(6.2)$ \\
& 100 & $22.3 \pm 0.91$ & $22.7 \pm 1.03$ & $0.2(0.9)$ \\
$\mathrm{AM}_{3}$ & 200 & $21.7 \pm 0.67$ & $22.8 \pm 0.78$ & $1.1(5.1)$ \\
& 400 & $21.2 \pm 0.45$ & $22.7 \pm 0.28$ & $1.5(7.1)$ \\
$\mathrm{CQ}$ & 100 & $20.6 \pm 0.48$ & $21.8 \pm 0.47$ & $1.2(5.8)$ \\
\end{tabular}

Values are presented as $M \pm S E M ; n$ refers to number of mice, $n=5 ; W_{t} D_{0}$ : weight before treatment on day zero; Wt $D_{4}$ : weight after treatment on fifth day (day 4); values in parenthesis indicate percent of change.

group. There was also statistically significant difference in the growth inhibition activity of chloroquine as compared with leaves latex and TLC isolates excluding $\mathrm{AM}_{3}$ at the highest dose.

Mean survival time (MST) of $P$. berghei infected mice was also recorded to evaluate an antimalarial activity of test substance. The mice treated with leaves latex and isolates of A. megalacantha at three different doses were observed to survive for longer time than the negative control group in a dose-dependent manner [Table 1]. $\mathrm{AM}_{3}$ treated group of mice were survived for longer time as compared with latex and other isolates, which were alive for $10.4 \pm 0.51$ days after treatment with at a dose of $400 \mathrm{mg} / \mathrm{kg}$ body weight with the corresponding negative control lived for $6.4 \pm 0.25$ days. Generally, the MST of the highest and higher doses of leaves latex, $\mathrm{AM}_{1}$ and $\mathrm{AM}_{2}$, and all doses of $\mathrm{AM}_{3}$ treated groups were statistically significant $(\mathrm{P}<0.05)$ when compared with distilled water treated group. Even though the MST obtained by latex, $\mathrm{AM}_{1}$ and $\mathrm{AM}_{2}$, at a dose of $100 \mathrm{mg} / \mathrm{kg}$ was statistically insignificant $(\mathrm{P}>0.05)$ when compared to negative control group, the mice were survived slightly longer time than negative control group. The chloroquine treated mice were alive beyond the follow-up period.

Another parameter that helps to identify antimalarial activity of the leaves latex is prevention of body weight loss in day 4 from day 0 . Although infection of mice with $P$. berghei caused about $4.6 \%$ body weight loss (as observed in the negative control), treating the mice with both the latex and TLC isolates was shielded from curtail of their body weight [Table 2]. All doses of both leaves latex and isolates were shown a dose-dependent weight gain in $P$. berghei infected mice except leaves latex treated mice at a dose of $100 \mathrm{mg} / \mathrm{kg} / \mathrm{day}$, which was observed to cause $0.4 \%$ of body weight loss. $\mathrm{AM}_{3}$ showed a higher weight gain relative to the standard drug, although the isolate did not eliminate the parasite completely. Therefore, the compound might have an ability to increase in body weight by different mechanisms.
Negative control group was noticed with $4.6 \%$ weight depreciation with the positive standard group gaining weight by $5.9 \%$.

Leaves latex treated mice at doses of 100, 200, and $400 \mathrm{mg} / \mathrm{kg}$ were observed to reduce their rectal temperature on fifth day of after infection by $6.6 \%, 4.6 \%$, and $3.7 \%$, respectively, while the negative control mice got hypothermic by $8.5 \%$ (lost $3.2^{\circ} \mathrm{C}$ ) [Table 3 ]. Moreover, the isolates were pointed out to prevent body temperature depreciation. As compared to the temperature loss of the negative control group, the isolate $\left(\mathrm{AM}_{1}, \mathrm{AM}_{2}\right.$, or $\left.\mathrm{AM}_{3}\right)$ treated mice were seen to improve their body temperature at doses of 100, 200, and $400 \mathrm{mg} / \mathrm{kg}$ body weight of mice in a dose-dependent manner. Chloroquine given mice were detected to prevent hypothermia caused due to the disease as the drug completely destructs the parasite from the blood of mice. At the first day before infection, mean rectal temperature of mice treated with leaf latex, isolates, or chloroquine was statistically not significant $(\mathrm{P}>0.05)$ as compared to negative control, conversely the observed prevention in rectal temperature loss after four day treatment with leaves latex, either of the isolates or of chloroquine, was statistically significant $(\mathrm{P}<0.001)$ as compared to negative control.

\section{Discussion}

The methanolic extract of leaves of $A$. debrana has shown a dose-dependent inhibition of parasitemia against Plasmodium berghei in mice with the highest $73.95 \%$ parasitaemia suppression observed at a dose of $600 \mathrm{mg} / \mathrm{kg} /$ day [9]. The dichloromethane/methanol extracts of $A$. ferox and A. maculate showed antiplasmodial activity with an $\mathrm{IC}_{50}=8$ and $12.4 \mathrm{mg} / \mathrm{mL}$, respectively [32].

The leaves latex of $A$. percrassa and compounds isolated from it, aloin $\mathrm{A} / \mathrm{B}$ and microdontin $\mathrm{A} / \mathrm{B}$, have been investigated for their in vivo antimalarial activity in $P$. berghei infected mice. Both the latex and the isolated compounds 
TABLE 3: Mean difference of rectal temperature of $P$. berghei infected mice after treatment with leaf latex and TLC isolates obtained from $A$. megalacantha.

\begin{tabular}{lcccc}
\hline Test substance & Dose $(\mathrm{mg} / \mathrm{kg} / \mathrm{day})$ & $\mathrm{T}^{0} \mathrm{D}_{0}\left({ }^{\circ} \mathrm{C}\right)$ & $\mathrm{T}^{0} \mathrm{D}_{4}\left({ }^{\circ} \mathrm{C}\right)$ & Mean difference \\
\hline $\mathrm{NC}$ & $10 \mathrm{ml} / \mathrm{kg}$ & $37.8 \pm 0.31$ & $34.6 \pm 0.33$ & $-3.2(8.5)$ \\
Latex & 100 & $38.02 \pm 0.22$ & $35.66 \pm 0.13 *$ & $-2.36(6.6)$ \\
& 200 & $37.45 \pm 0.26$ & $35.82 \pm 0.31 *$ & $-1.63(4.6)$ \\
& 400 & $37.5 \pm 0.28$ & $36.16 \pm 0.21 *$ & $-1.34(3.7)$ \\
$\mathrm{AM}_{1}$ & 100 & $37.7 \pm 0.19$ & $35.9 \pm 0.29 *$ & $-1.7(4.5)$ \\
& 200 & $37.6 \pm 0.37$ & $36.6 \pm 0.22 *$ & $-1.0(2.7)$ \\
$\mathrm{AM}_{2}$ & 400 & $37.7 \pm 0.33$ & $36.8 \pm 0.27 *$ & $-0.9(2.4)$ \\
& 100 & $37.6 \pm 0.30$ & $36.1 \pm 0.50 *$ & $-1.5(4.0)$ \\
$\mathrm{AM}_{3}$ & 200 & $37.4 \pm 0.28$ & $36.6 \pm 0.52 *$ & $-0.8(2.1)$ \\
& 400 & $37.4 \pm 0.26$ & $36.7 \pm 0.31 *$ & $-0.7(1.9)$ \\
$\mathrm{CQ}$ & 100 & $37.6 \pm 0.24$ & $36.5 \pm 0.17 *$ & $-1.1(2.9)$ \\
\hline
\end{tabular}

Values are presented as $\mathrm{M} \pm \mathrm{SEM} ; \mathrm{n}=5 ; *$ mean value is significant $(\mathrm{P}<0.001)$ when compared with negative control group; $\mathrm{T}^{0} \mathrm{D}_{0}$ : temperature before treatment on day zero; $\mathrm{T}^{0} \mathrm{D}_{4}$ : temperature after treatment on fifth day (day 4 ); values in parenthesis indicate $\%$ of change.

possessed significant antimalarial activity with parasitemia suppression of $73.6 \%$ from latex treatment [22]. Similarly, the leaves latex of $A$. pulcherrima possesses in vivo antimalarial activity in mice infected with the rodent parasite $P$. berghei. Furthermore, a significant reduction of parasitemia was observed in groups treated with the isolated compounds, nataloin, and 7-hydroxyaloin, specifically at a dose of $200 \mathrm{mg} / \mathrm{kg}$ [24]. Homonataloin A/B has been isolated as a major component of the latex of $A$. citrana and both the latex and homonataloin A/B exhibited significant antimalarial activity in $P$. berghei infected mice [23].

Moreover, in vitro antimalarial test of ether leaves extracts of $A$. dawei using the chloroquine diphosphate as control has shown a potential inhibition of parasite growth against $P$. falciparum [33]. Similarly, Aloe perryi has been studied for its in vitro antiplasmodial activity and the result supports the use of the plant leaves latex in the treatment of malaria [34]. In vitro antiplasmodial activity test of aqueous leaf extract and isolated compounds of $A$. vera collected from different climatic regions in India has been conducted. Different chmosuppressive effect of samples collected from different climatic area has been observed with $\mathrm{EC}_{50}$ values ranging from 0.289 to $1056 \mu \mathrm{g} / \mathrm{ml}$. Aloin and aloe-emodin, the compounds isolated from $A$. vera leaf extract, have been shown to possess dosedependent antiplasmodial activity with $\mathrm{EC}_{50}$ value $67 \mu \mathrm{g} / \mathrm{ml}$ and $22 \mu \mathrm{g} / \mathrm{ml}$, respectively. The standard drug, chloroquine, has been reported with $0.034 \mu \mathrm{g} / \mathrm{ml}$ EC50 value [21].

Similarly in this study, both leaves latex of $A$. megalacantha and TLC isolates obtained from the latex revealed a significant dose-dependent chemosuppression activity against $P$. berghei in Swiss albino mice. The observed activity could be due to single or combined action of secondary metabolites found in the leaf latex. In this study, the individual isolates show better parasite growth inhibition when administered separately than the leaves latex. This could be due to the antagonism effect of either the isolates obtained or minor compounds found in the leaves latex which can lead to cancel in part the antimalarial activity of compounds.

According to Zeleke et al., in vivo antimalarial activity can be classified as moderate, good, and very good if an extract showed percent growth inhibition $\geq 50 \%$ at a dose of 500, 250, and $100 \mathrm{mg} / \mathrm{kg}$ body weight/day, respectively [35]. Based on this, leaves latex of $A$. megalacantha had shown a moderate antiplasmodial activity against $P$. berghei infected mice.

Mean survival time (MST) of $P$. berghei infected mice is another parameter to evaluate an antimalarial activity of test substance. It has been reported that dose-dependent mean survival time of the mice treated with leaves latex and isolated compounds of $A$. percrassa was observed and has been reported as it was statistically significant as compared to the negative control group [22]. Mice treated with latex and compounds isolated from $A$. pulcherrima have been survived for longer time than the negative control group, even though it was not in a dose-dependent manner and not statistically significant as compared to negative control [24].

Similarly, the survival time of mice treated with either leaves latex or TLC isolates of $A$. megalacantha was observed in a dose-dependent phenomenon. This might happen due to its suppressive effect on the parasite growth. Even though the mean survival time of mice treated with latex, $\mathrm{AM}_{1}$ or $\mathrm{AM}_{2}$, at a dose of $100 \mathrm{mg} / \mathrm{kg}$ was not significant, they were survived for longer time relative to the negative control group. All mice treated with the latex and isolates at 200 and $400 \mathrm{mg} / \mathrm{kg}$ were shown a significant survival time $(\mathrm{P}<0.05)$ compared to vehicle treated mice.

The isolates obtained from leaves latex of A. megalacantha are believed to be anthraquinones and/or their oxidative derivatives because of having similar physical appearance and retention factor $\left(R_{f}\right)$ values on TLC with anthrones and other anthraquinones derivatives isolated from leaves latex of A. harlana [36], A. percrassa [22], A. citrina [23], A. trigonantha [37], A. pulcherrima [24], A. sinana [38], A. 
marlothii, and A. rupestris [29]. It has been also reported that leaves of Aloe species are store house of anthraquinones and other metabolites [28]. This proposition is also supported by the report of Abdissa et al., who described the presence of anthraquinones and preanthraquinones like chrysophanol, aloesaponarin I, aloesaponarin II, and aloesaponarin III in ethyl acetate root extract of $A$. megalacantha [26].

Body weight loss and reduction in rectal temperature are the key characteristic of rodent malaria. Basir et al. have described weight loss as one of the dramatic manifestations of rodent malaria. This could be due to reduced food and water intake. They have reported that progression of complications like severe anemia and hypoglycemia could be another possible mechanism which leads to break down of lipids and proteins as a source of energy which can lead to weight loss [31]. Treatment of $P$. berghei infected mice with leaf latex and isolated compounds of A. percrassa [22], A. citrina [23], and $A$. pulcherrima [24] has shown dose-dependent weight loss reduction. Furthermore, significant reduction of colonic temperature has been also seen through infection of mice with $P$. berghei [31].

In the current study, weight loss and hypothermia were observed in the vehicle treated $P$. berghei infected mice. However, treatment with leaves latex and isolates of $A$. megalacantha was shown to reduce malaria caused weight loss and hypothermia. The isolate $\mathrm{AM}_{3}$ showed greater increase in weight as compared to chloroquine. Thus, the observed weight gain after treatment with leaves latex and isolates could be attributed to enhanced food intake of mice and/or inhibited pathophysiology of the disease. Hence, all the leaves latex and TLC isolates revealed preventive effect in reducing hypothermia with the highest effect observed in the isolates. The possible mechanism of prevention could be due to reduced debilitation of parasitemia as hypothermia is directly proportional to the parasitemia. Increased appetite could also be attributed to reduction in hypothermia by increasing body weight.

\section{Conclusion}

From the findings of the present study, a significant dosedependent chemosuppression of both leaves latex and TLC isolates obtained from $A$. megalacantha was observed in $P$. berghei infected mice. Moreover, both the leaves latex and isolates could be considered safe at a single dose of $2000 \mathrm{mg} / \mathrm{kg}$ as they did not cause any manifestation of acute toxicity. The antimalarial activity of the leaves latex of this plant in part may be attributed to the presence of $A M_{1}, \mathrm{AM}_{2}$, and $\mathrm{AM}_{3}$, which require further purification and elucidation of the structures of the isolated compound, could serve as the starting compound for the development of novel synthetic antimalarial drugs. Thus, results of the present study justify and may also support the traditional use of the plant as antimalarial agent.

\section{Abbreviations}

$\mathrm{EC}_{50}$ : Effective oncentration at 50\%

EPHI: Ethiopian Public Health Institute
$\mathrm{IC}_{50}$ : of a substance $50 \%$

MST: Mean urvival ime

OECD: Organization for Economic Cooperation and Development

RBC: Red Blood Cells

TLC: Thin ayer hromatography

UV: Ultraviolet

WHO: World Health Organization.

\section{Data Availability}

The datasets used and/or analyzed during the current study are available from the corresponding author on reasonable request.

\section{Ethical Approval}

The experimental animals were used and sacrificed in accordance with the procedure approved by the Health Research and Ethics Review Committee in College of Health Sciences, Mekelle University. The study was implemented with the approval registration number ERC 0964/2017.

\section{Conflicts of Interest}

The authors declare that they have no conflicts of interest.

\section{Authors' Contributions}

Gebretsadkan Hintsa prepared the proposal, performed the experimentation, analyzed the results, and was a major contributor in writing the manuscript. Gereziher Geremedhin Sibhat criticized the methodology and did pretests for each experiment. Aman Karim designed the isolation methodology part. All authors read and approved the final manuscript.

\section{Acknowledgments}

Gebretsadkan Hintsa acknowledges MU-NMBU for the fund offered and Addis Pharmaceutical Factory S.C. for the consumables supported. Gebretsadkan Hintsa also appreciates Professor Sebsebe Demissew for his cooperation in authentication of the plant. This study was done by grant obtained from MU-NMBU of Mekelle University [MU/CHS/1651/2017], Ethiopia, for data collection only.

\section{References}

[1] T. F. De Koning-Ward, M. W. A. Dixon, L. Tilley, and P. R. Gilson, "Plasmodium species: master renovators of their host cells," Nature Reviews Microbiology, vol. 14, no. 8, pp. 494-507, 2016.

[2] World Health Organization, World Malaria Report 2017, Geneva, Switzerland, 2017, Licence: CC BY-NC-SA 3.0 IGO.

[3] A. O. Talisuna, P. Bloland, and U. D’Alessandro, "History, dynamics, and public health importance of malaria parasite resistance," Clinical Microbiology Reviews, vol. 17, no. 1, pp. 235254, 2004. 
[4] H. Ginsburg and E. Deharo, "A call for using natural compounds in the development of new antimalarial treatments-an introduction," Malaria Journal, vol. 10, pp. 1-7, 2011.

[5] B. T. Grimberg and R. K. Mehlotra, "Expanding the antimalarial drug arsenal-now, but how?" Pharmaceuticals, vol. 4, no. 5, pp. 681-712, 2011.

[6] M. A. Alshawsh, R. A. Mothana, H. A. Al-shamahy, S. F. Alsllami, and U. Lindequist, "Assessment of antimalarial activity against Plasmodium falciparum and phytochemical screening of some Yemeni medicinal plants," Evidence-Based Complementary and Alternative Medicine, vol. 6, no. 4, pp. 453-456, 2009.

[7] A. Teklay, B. Abera, and M. Giday, "An ethnobotanical study of medicinal plants used in Kilte Awulaelo district, Tigray Region of Ethiopia," Journal of Ethnobiology and Ethnomedicine, vol. 9, pp. 1-23, 2013.

[8] S. Asnake, T. Teklehaymanot, A. Hymete, B. Erko, and M. Giday, "Survey of medicinal plants used to treat malaria by Sidama people of Boricha district, Sidama zone, South Region of Ethiopia," Evidence-Based Complementary and Alternative Medicine, vol. 2016, Article ID 9690164, 9 pages, 2016.

[9] T. Deressa, Y. Mekonnen, and A. Animut, "In vivo antimalarial activities of Clerodendrum myricoides, Dodonea angustifolia and Aloe debrana against Plasmodium berghei," Ethiopian Journal of Health Development, vol. 24, no. 1, pp. 25-29, 2010.

[10] A. Mesfin, M. Giday, A. Animut, and T. Teklehaymanot, "Ethnobotanical study of antimalarial plants in Shinile District, Somali Region, Ethiopia, and in vivo evaluation of selected ones against Plasmodium berghei," Journal of Ethnopharmacology, vol. 139, no. 1, pp. 221-227, 2012.

[11] C. S. Bjora, E. Wabuyele, O. M. Grace, I. Nordal, and L. E. Newton, "The uses of Kenyan aloes: An analysis of implications for names, distribution and conservation," Journal of Ethnobiology and Ethnomedicine, vol. 11, no. 1, pp. 82-97, 2015.

[12] M. Giday, Z. Asfaw, and Z. Woldu, "Medicinal plants of the Meinit ethinic group of Ethiopia: an Ethnobotanical study," Journal of Ethnopharmacology, vol. 124, no. 3, pp. 513-521, 2009.

[13] K. Asres, F. Bucar, E. Knauder, V. Yardley, H. Kendrick, and S. L. Croft, "In vitro antiprotozoal activity of extract and compounds from the stem bark of Combretum molle," Phytotherapy Research, vol. 15, no. 7, pp. 613-617, 2001.

[14] R. R. Klopper and G. F. Smith, "Aloes of the world: When, where and who?" 2010, https://www.researchgate.net/publication/242019243_Aloes_of_the_world_When_where_and_who.

[15] S. Demissew and I. Nordal, Aloes and Lilies of Ethiopia and Eritrea, Shama Books, Addis Ababa, Ethiopia, 1st edition, 2010.

[16] S. Demissew, I. Friis, T. Awas et al., "Four new species of Aloe (Aloaceae) from Ethiopia, with notes on the ethics of describing new taxa from foreign countries," Kew Bulletin, vol. 66, no. 1, pp. 111-121, 2011.

[17] I. E. Cock, “The genus aloe: Phytochemistry and therapeutic uses including treatments for gastrointestinal conditions and chronic inflammation," Progress in Drug Research, vol. 70, pp. 179-235, 2015.

[18] A. Belayneh and N. F. Bussa, "Ethnomedicinal plants used to treat human ailments in the prehistoric place of Harla and Dengego valleys, eastern Ethiopia," Journal of Ethnobiology and Ethnomedicine, vol. 10, pp. 18-25, 2014.

[19] S. Araya, B. Abera, and M. Giday, "Study of plants traditionally used in public and animal health management in Seharti Samre District, Southern Tigray, Ethiopia," Journal of Ethnobiology and Ethnomedicine, vol. 11, pp. 1-5, 2015.
[20] A. Kebede, S. Ayalew, A. Mesfin, and G. Mulualem, "Ethnobotanical investigation of traditional medicinal plants commercialized in the markets of Dire Dawa city, eastern Ethiopia," Journal of Medicinal Plants Studies, vol. 4, pp. 170-178, 2016.

[21] S. Kumar, M. Yadav, A. Yadav, P. Rohilla, and J. P. Yadav, "Antiplasmodial potential and quantification of aloin and aloeemodin in Aloe vera collected from different climatic regions of India," BMC Complementary and Alternative Medicine, vol. 17, article 369, 2017.

[22] G. Geremedhin, D. Bisrat, and K. Asres, "Isolation, characterization and in vivo antimalarial evaluation of anthrones from the leaf latex of aloe percrassa todaro," Journal of Natural Remedies, vol. 14, pp. 120-125, 2014.

[23] B. Girma, D. Bisrat, and K. Asres, "Antimalarial evaluation of the leaf latex of Aloe citrina and its major constituent," Ancient Science of Life, vol. 34, pp. 142-146, 2015.

[24] T. Teka, D. Bisrat, M. Y. Yeshak, and K. Asres, "Antimalarial activity of the chemical constituents of the leaf latex of aloe pulcherrima gilbert and sebsebe," Molecules, vol. 21, article 1415, 2016.

[25] L. Gebremeskel, D. Bhoumik, G. G. Sibhat, and K. B. Tuem, "In vivo wound healing and anti-inflammatory activities of leaf latex of aloe megalacantha baker (Xanthorrhoeaceae)," Evidence-Based Complementary and Alternative Medicine, vol. 2018, Article ID 5037912, 7 pages, 2018.

[26] N. Abdissa, S. Gohlke, M. Frese, and N. Sewald, "Cytotoxic Compounds from Aloe megalacantha," Molecules, vol. 22, no. 7, pp. 1136-1145, 2017.

[27] B. Tadesse, G. Terefe, N. Kebede, and W. Shibeshi, "In Vivo anti-trypanosomal activity of dichloromethane and methanol crude leaf extracts of Dovyalis abyssinica (Salicaceae) against Trypanosoma congolense," BMC Complementary and Alternative Medicine, vol. 15, article 278, 2015.

[28] E. Dagne, D. Bisrat, A. Viljoen, and B.-E. Van Wyk, "Chemistry of Aloe species," Current Organic Chemistry, vol. 4, no. 10, pp. 1055-1078, 2000.

[29] Organization for Economic Co-Operation and Development (OECD), "OECD guidelines for the testing of chemicals: Acute Oral Toxicity Up and Down-Procedure (UDP)," pp. 1-27, 2008.

[30] W. Peters, B. L. Robinson, G. Tovey, J. C. Rossier, and C. W. Jefford, "The chemotherapy of rodent malaria L. The activities of some synthetic 1,2,4-trioxanes against chloroquine sensitive and chloroquine-resistant parasites. Part 3: Observations on 'Fenozan-50F', a difluorinated 3,3'-spirocyclopentane 1,2,4trioxane," Annals of Tropical Medicine and Parasitology, vol. 87, no. 2, pp. 111-123, 1993.

[31] R. Basir, S. S. F. Rahiman, K. Hasballah et al., "Plasmodium berghei ANKA infection in ICR mice as a model of cerebral malaria," Iranian Journal of Parasitology, vol. 7, no. 4, pp. 62-74, 2012.

[32] C. Clarkson, V. J. Maharaj, N. R. Crouch et al., "In vitro antiplasmodial activity of medicinal plants native to or naturalized in South Africa," Journal of Ethnopharmacology, vol. 92, no. 2-3, pp. 177-191, 2004.

[33] G. S. Bbosa, D. B. Kyegombe, A. Lubega et al., "Anti-Plasmodium falciparum activity of Aloe dawei and Justicia betonica," African Journal of Pharmacy and Pharmacology, vol. 7, no. 31, pp. 2258-2263, 2013.

[34] R. A. Mothana, N. M. Al-Musayeib, A. Matheeussen, P. Cos, and L. Maes, "Assessment of the in vitro antiprotozoal and cytotoxic potential of 20 selected medicinal plants from the island of soqotra," Molecules, vol. 17, no. 12, pp. 14349-14360, 2012. 
[35] G. Zeleke, D. Kebebe, E. Mulisa, and F. Gashe, "In vivo antimalarial activity of the solvent fractions of fruit rind and root of Carica papaya Linn (Caricaceae) against Plasmodium berghei in mice," Journal of Parasitology Research, vol. 2017, Article ID 3121050, 9 pages, 2017.

[36] G. Asamenew, D. Bisrat, A. Mazumder, and K. Asres, "In vitro antimicrobial and antioxidant activities of anthrone and chromone from the latex of Aloe harlana reynolds," Phytotherapy Research, vol. 25, no. 12, pp. 1756-1760, 2011.

[37] M. Megeressa, D. Bisrat, A. Mazumder, and K. Asres, "Structural elucidation of some antimicrobial constituents from the leaf latex of Aloe trigonantha L.C. Leach," BMC Complementary and Alternative Medicine, vol. 15, pp. 270-276, 2015.

[38] G. Minale, D. Bisrat, K. Asres, and A. Mazumder, "In vitro antimicrobial activities of anthrones from the leaf of Aloe sinana Reynolds,' International Journal of Green Pharmacy, vol. 8, pp. 7-12, 2014. 


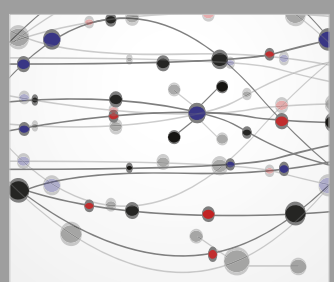

The Scientific World Journal
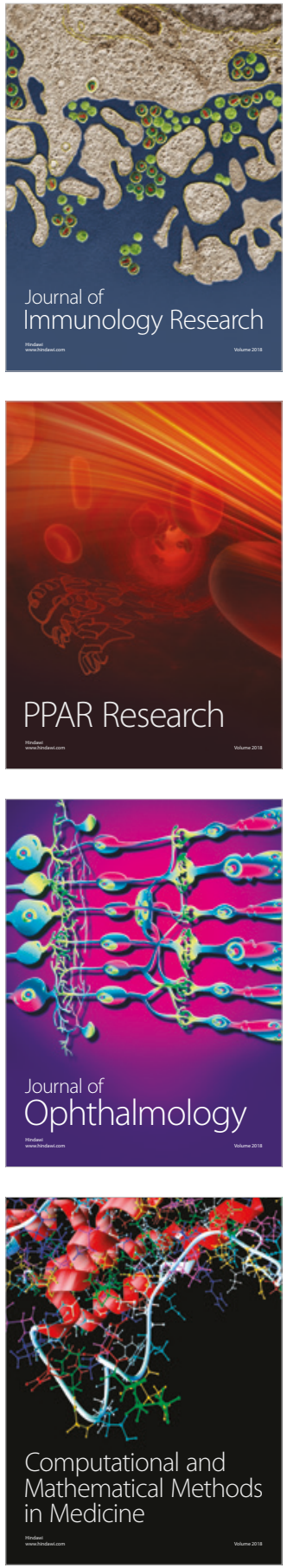

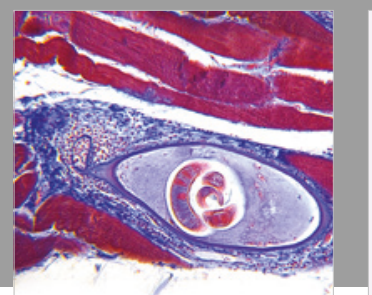

Gastroenterology Research and Practice

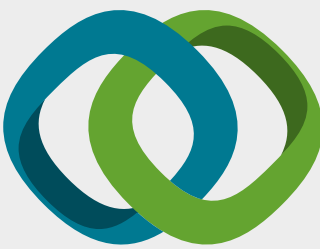

\section{Hindawi}

Submit your manuscripts at

www.hindawi.com
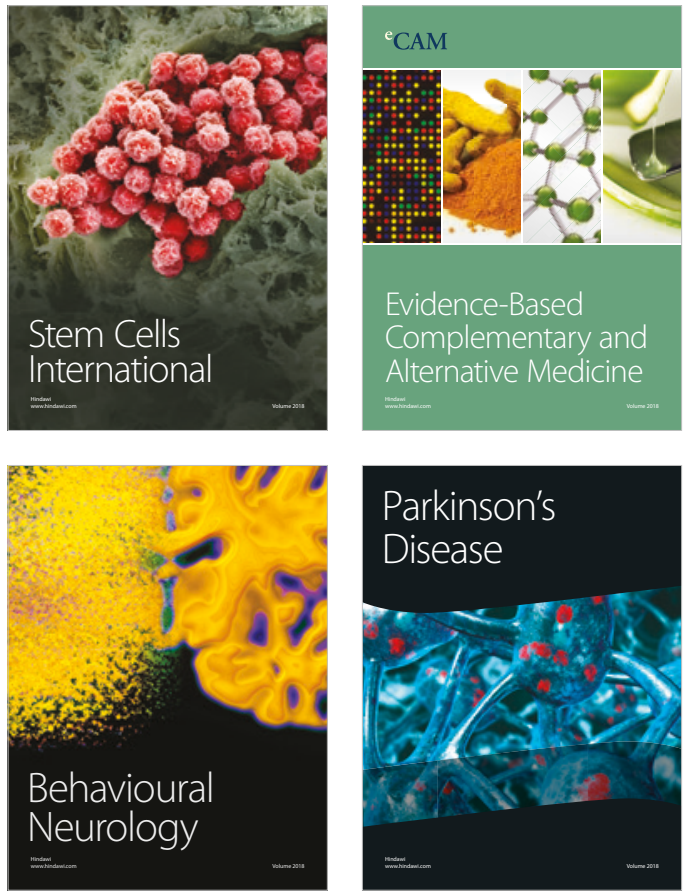

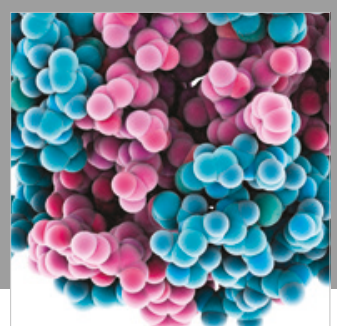

ournal of

Diabetes Research

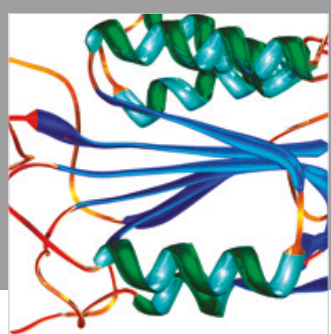

Disease Markers
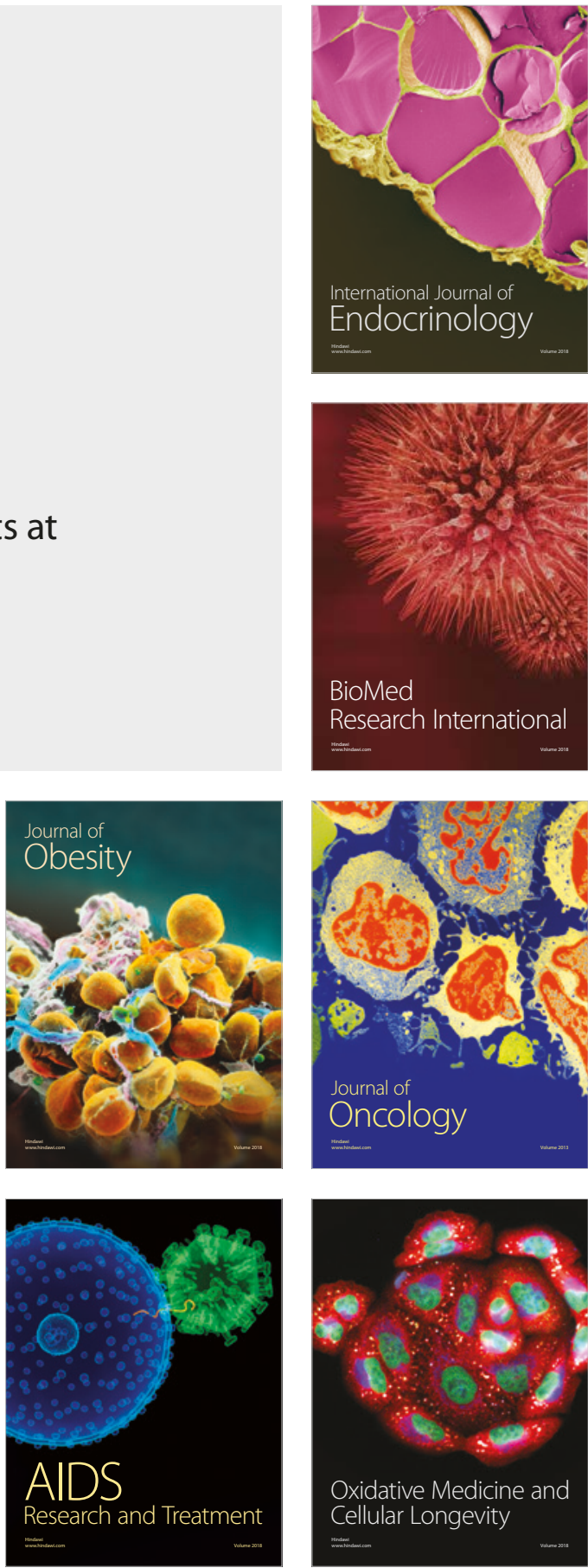